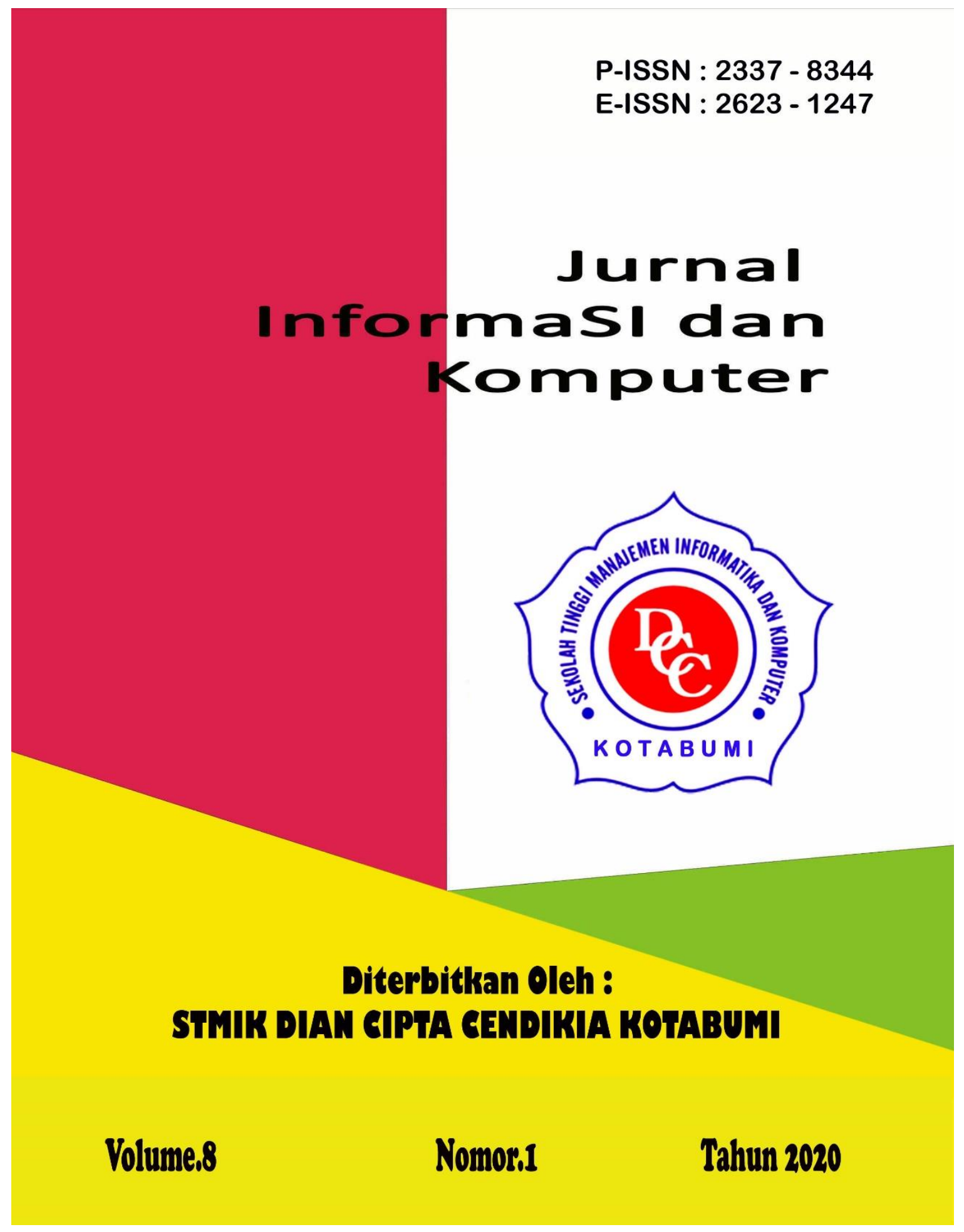




\section{Penerbit:}

STMIK DIAN CIPTA CENDIKIA KOTABUMI

Bekerjasama dengan LPPM STMIK DCC Kotabumi

Hak atas naskah/tulisan tetap berada pada penulis, isi diluar tanggung jawab Penerbit dan Dewan Penyunting

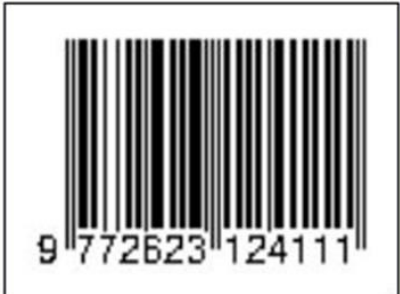




\section{PENGANTAR REDAKSI}

Puji syukur dipanjatkan kehadirat Tuhan Yang Maha Esa, atas karunia dan limpahan rahmatNYA jualah Jurnal Informatika dan komputer (InfoKom) STMIK Dian Cipta Cendikia Kotabumi ini dapat terwujud.Jurnal Informatika dan Komputer (InfoKom) yang terbit dua (2) kali dalam setahun ini merupakan suatu wadah untuk penyebar luasan hasil-hasil penelitian, studi pustaka, karya ilmiah yangberkaitan dengan Informatika dan Komputer khususnya bagi dosen-dosen STMIK Dian Cipta Cendikia Kotabumi serta umumnya para cendikiawan, praktisi, peneliti ilmu Informatika dan Komputer.

Harapan, dengan diterbitkannya Jurnal Informatika dan Komputer (InfoKom) ini sebagai salah satu bentuk sumbangan pemikiran dalam pengembangan ilmu informatika dan komputer yang berkaitan dengan kajian-kajian di bidang tekhnologi Informatik, Komunikasi Data dan Jaringan Komputer, perancangan dan Rekayasa Perangkat Lunak, serta ilmu-ilmu yang terkait dengan bidang Informatika dan Komputer lainnya.

Berkenaan dengan harapan tersebut, kepada para peneliti, dosen dan praktisi yang memiliki hasil-hasil penelitian, kajian pustaka, karya ilmiah dalam bidang tersebut diatas, dengan bangga redaksi Jurnal Informatika dan Komputer (JIK) menerima naskah ringkasan untuk dimuat pada jurnal Informatika dan Komputer (InfoKom) STMIK Dian Cipta Cendikia Kotabumi dengan berpedoman pada penulisan naskah jurnal sebagaimana dilampirkan pada halaman belakang (Bagian kulit dalam) buku jurnal ini.

Mutu dari suatu jurnal ilmiah tidak hanya ditentukan oleh para pengelolanya saja, tetapi para penulis dan pembaca jualah yang mempunyai peranan besar dalam meningkatkan mutu jurnal Informatika dan Komputer ini. Merujuk pada realita ini kamu sangat mengharapkan peran aktif dari peneliti untuk bersama-sama menjaga dan memelihara keberlangsungan dari jurnal Informatika dan Komputer STMIK Dian Cipta Cendikia Kotabumi ini. Yang juga tidak kalah pentingnya dari partisipasi tersebut diatas, adalah saran dan kritik yang membangun dari pembaca yang budiman agar kiranya dapat disampaikan langsung kepada redaksi JIK. Saran dan kritik yang membangun akan dijadikan masukan dan pertimbangan yang sangat berarti guna peningkatan mutu dan kualitas Jurnal Informatika dan Komputer STMIK Dian Cipta Cendikia Kotabumi.

Tak lupa diucapkan terima kasih yang tak terhingga atas perhatian dan kerjasama dari semua pihak yang tak dapat disebutkan satu persatu hingga dapat diterbitkan nya Jurnal Informatika dan Komputer (InfoKom) STMIK Dian Cipta Cendikia Kotabumi. Semoga apa yang telah diperbuat untuk kebaikan akan menjadi amal ibadah, amin.

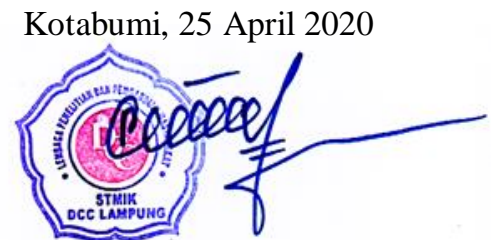

Dewan Redaksi 


\section{JURNAL INFORMASI DAN KOMPUTER Volume 8 Nomor 1 April 2020}

Jurnal Informasi dan Komputer merupakan Sarana informasi ilmu pengetahuan, Tekhnologi dan Komunikasi yang berupa hasil penelitian, tulisan ilmiah, Ataupun studi pustaka. Jurnal ini terbit dua kali setahun pada bulan April dan Oktober. Berisi hasil penelitian ilmiah di bidang informatika yang bertujuan untuk menghubungkan adanya kesenjangan antar kemajuan teknologi dan hasil penelitian. Jurnal ini di terbitkan pertama kali pada tahun 2013.

Penanggung Jawab:

Ketua STMIK Dian Cipta Cendikia

Kotabumi

\section{Pembina:}

Ketua STMIK Dian Cipta Cendikia

Kotabumi

Ketua Lembaga Penelitian STMIK Dian

Cipta Cendikia Kotabumi

\section{Pimpinan Redaksi}

Dwi Marisa Efendi,.S.Kom.,M.Ti

\section{Redaksi pelaksana}

Rustam,.S.Kom,.M.Ti (STMIK Dian

Cipta Cendikia Kotabumi)

Nurmayanti M.Kom (STMIK Dian

Cipta Cendikia Kotabumi)

Sukatmi,.S.Kom., M.Kom (AMIK DCC

Bandar Lampung)

Sampurna Dadi Riskiono,M.Kom

(Universitas Teknokrat Indonesia)

Ifo Wahyu

Pratama,S.Kom.,M.Ti(AMIK MASTER

Lampung)

\author{
Mitra Bestari \\ Merri Parida.,M.Kom (STMIK Dian \\ Cipta Cendikia Kotabumi) \\ Amarudin,S.Kom.,M.Eng (Universitas \\ Teknokrat Indonesia) \\ Didi Susianto.,S.T.,M.Kom (AMIK \\ DCC Bandar Lampung) \\ Alhibarsyah.,S.T.,M.Kom (Stmik Tunas \\ Bangsa Bandar Lampung) \\ Kemal Farouq Mauladi \\ .,S.Kom.,M.Kom (Universitas Islam \\ Lamongan) \\ Agus Setiawan S.Pd.,M.Eng \\ (Universitas Muhammadiyah \\ Lamongan)
}

Penerbit : STMIK Dian Cipta Cendikia Kotabumi Bekerja Sama Dengan LPPM STMIK Dian Cipta Cendikia Kotabumi.
Alamat Redaksi/Penerbit:
Jl. Negara No. 3 Candimas Kotabumi
Lampung Utara
No Telpon/Fax 072423003
Email : 1ppm-stmik@dcc.ac.id 


\section{DAFTAR ISI}

\section{Halaman}

Sistem Pendukung Keputusan Penentuan Lahan Kopi Terbaik Dengan Metode Ahp (Analytic Hierarchy Process)

Sidik Rahmatullah, Rendy Abdurahman (AMIKKOM Jogja,

STMIK Dian Cipta Cendikia Kotabumi)

Rancang Bangun Sistem Informasi Pada Program Pembangunan Pemberdayaan

Masyarakat Desa( P3md ) Berbasis Web Mobile

Ferly Ardhy, Firmansyah, Sidik Rahmatullah,(IIB Darma Jaya Bandar Lampung

STMIK Dian Cipta Cendikia Kotabumi, AMIKKOM Jogja)

Sistem Informasi Pengolahan Data Alumni Sekolah Menengah Atas (Sma)

Merri Parida, Nindiya Ova Rahmawati (AMIKKOM Jogja,

STMIK Dian Cipta Cendikia Kotabumi)

SISTEM INFORMASI GEOGRAFIS PUSKESMAS BESERTA SARANA

DAN PRASARANA BERBASIS WEB MOBILE

Nurmayanti, Windy Dwi Bahari (AMIKOM Jogja,

STMIK Dian Cipta Cendikia Kotabumi)

Rancang Bangun Sistem Informasi Konseling Untuk Sekolah Menengah Kejuruan

(Smk) Berbasis Website

Aliy Hafiz1, Galih Rakasiwi, Ifo Wahyu Pratama, Agus Komarudin,

Bambang Suparapto, Fathurrahman Kurniawan Ikhsan

(AMIK Dian Cipta Cendikia Bandar Lampung,

Universitas Nahdhatul Ulama Lampung, AMIK Dian Cipta Cendikia Pringsewu,

Universitas Mitra Indonesia, Lampung) .....

Sistem Pendukung Keputusan Pemilihan Driver Terbaik Menggunakan Metode

Weight Product (Wp)

Dina Lorenza, Pitrawati (STMIK Dian Cipta Cendikia Kotabumi

AMIK Dian Cipta Cendikia)

Rancang Bangun Sistem Informasi Pembayaran Mahasiswa

Darsin(Universitas Megou pak Tulang Bawang)

Sistem Informasi Geografis Bengkel Motor Honda Resmi Bandar Lampung

Sukatmi, Nuraini (AMIK Dian Cipta Cendikia Bandar Lampung).....

Sistem Pakar Diagnosa Penyakit Kulit Wajah Dengan Metode

Certainty Factor Pada Klinik Skin Rachel

Dwi Marisa Efendi, Putri Yulita Sari (IIB Darmajaya Bandar Lampung,

STMIK Dian Cipta Cendikia Kotabumi) 
Sistem Informasi Monitoring Siswa Pada Mts Al-Islamiah Bunut Kabupaten Pesawaran Yuli Syafitri ${ }^{2}$, Reni Astika ${ }^{1}$, Septian Hernando ${ }^{3}$

Aplikasi Kamus Bahasa Jepang Berbasis Mobile Android Rustam $^{2}$ A Yanda Febry Pangestu ${ }^{2}$ Sistem Informasi, Teknologi Komputer ${ }^{1}$, IIB Darmajaya Bandar Lampung ${ }^{2}$ STMIK Dian Cipta Cendikia Kotabumi 


\title{
RANCANG BANGUN SISTEM INFORMASI KONSELING UNTUK SEKOLAH MENENGAH KEJURUAN (SMK) BERBASIS WEBSITE
}

\author{
Aliy Hafiz ${ }^{1}$, Galih Rakasiwi ${ }^{2}$, Ifo Wahyu Pratama ${ }^{3}$, Agus Komarudin ${ }^{4}, B^{3}$ Babang \\ Suparapto ${ }^{5}$,Fathurrahman Kurniawan Ikhsan ${ }^{6}$ \\ 1,2,3 Manajemen Informatikan, AMIK Dian Cipta Cendikia \\ ${ }^{4}$ Universitas Nahdhatul Ulama, Lampung \\ ${ }^{5}$ Manajemen Informatikan, AMIK Dian Cipta Cendikia Pringsewu \\ ${ }^{5}$ Universitas Mitra Indonesia, Lampung \\ Jl. Cut Nyak Dien No. 65 Durian Payung (Palapa) Bandar Lampung

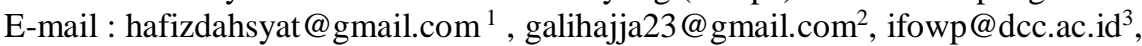 \\ agus.komarudin@unulampung.ac.id ${ }^{4}$,supraptobambang88@gmail.com ${ }^{5}$,fatkuriks@gmail.com ${ }^{6}$
}

\begin{abstract}
ABSTRAK
Sekolah Menengah Kejuruan (SMK) AZZA WA JALLA Bandar Lampung merupakan sekolah yang mempunyai dua kejuruan yaitu keperawatan dan farmasi. pada bagian bimbingan konseling penanganan data siswa yang meliputi data pribadi siswa, data bimbingan dan pelanggaran tata tertib siswa masih dilakukan secara manual dicatat dengan buku. Banyaknya jumlah siswa dan data yang harus dimasukkan menjadi kendala dalam perekapan, pencarian dan pembaharuan data.Penelitian ini dilakukan dengan menggambil data bimbingan konseling untuk mengatasi pengolahan data dan pencatatan data. Metode pengembangan sistem menggunakan metode Extreme Programming. Alat perancangan Unified Modelling Language $(U M L)$ diagram yang terdiri dari use case diagram, class diagram, dan activity diagram. Dari penelitian ini dihasilkan sebuah sistem informasi bimbingan konseling yang mampu mengola data lebih baik dibandingkan dengan sitem yang lama. Aplikasi yang dikembangkan dapat membantu meningkatkan kinerja guru SMK AZZA WA JALLA Bandar Lampung dalam penyusunan laporan data siswa, laporan bimbingan konseling persiswa, laporan bimbingan konseling bulanan, dan laporan bimbingan konseling tahunan.
\end{abstract}

Kata kunci: Extreme Programming, Unified Modelling Language (UML),Konseling,Kejuruan.

\begin{abstract}
ABSTRAK
AZZA WA JALLA Vocational High School (SMK) Bandar Lampung is a school that has two vocational schools namely nursing and pharmacy. in the counseling guidance section handling student data which includes personal data of students, guidance data and violations of student discipline are still done manually recorded with books. The large number of students and data that must be entered becomes an obstacle in the recording, searching and updating data. This research was conducted by taking counseling guidance data to overcome data processing and data recording. The system development method uses the Extreme Programming method. The Unified Modeling Language (UML) diagram design method consists of use case diagrams, class diagrams, and activity diagrams. From this study produced a counseling guidance information system that is able to manage data better than the old system. The developed application can help improve the performance of SMK AZZA WA JALLA Bandar Lampung teachers in the preparation of student data reports, exact guidance counseling reports, monthly counseling guidance reports, and annual counseling guidance reports.
\end{abstract}

Keywords: Extreme Programming, Unified Modelling Language (UML), counseling, Vocational.

1. PENDAHULUAN

33 ISTMIK DIAN CIPTA CENDIKIA KOTABUMI
Perkembangan ilmu pengetahuan dan teknologi pada era modern saat ini sudah merambah ke 
berbagai sisi kehidupan manusia. Teknologi infomasi adalah salah satu dari perkembangan teknologi yang berkembang pesat saat ini, sehingga kebutuhan akan informasi akan terus bertambah dan dibutuhkan. Perkembangan teknologi informasi dapat dimanfaatkan dalam berbagai bidang salah satunya pada bidang Pendidikan khususnya yaitu bimbingan dan konseling di sekolah. (Dicky Eka, 2018).

Dengan adanya teknologi informasi untuk pendidikan berbagai macam informasi pendidikan dengan mudah dan cepat dapat diakses. Informasi pendidikan tersebut diantaranya pembelajaran menggunakan elearning, sistem informasi sekolah, dan masih banyak lagi (Yaumi dkk, 2017). Teknologi informasi untuk pendidikan ini meliputi segala hal yang berkaitan dengan proses pembelajaran, penggunaan sebagai alat bantu, dan pengelolaan data menjadi informasi yang berhubungan dengan pendidikan.

Aplikasi teknologi informasi di dunia pendidikan bertujuan untuk mengelola proses data guna membantu proses belajar mengajar maupun dalam administrasi pendidikan. Tujuan lain adalah memfasilitasi dunia pendidikan dalam meningkatkan kinerja dengan membuat dan menggunakan sebuah aplikasi sistem informasi pendidikan yang mampu memberikan informasi yang dibutuhkan. Dengan tujuan tersebut, maka dibuatlah aplikasi sistem informasi yang dapat digunakan oleh instansi pendidikan untuk mengolah data secara cepat dan tepat (Setiawan A, 2019).

Observasi yang dilakukan di SMK Azza Wa Jalla Bandar Lampung, pada bagian bimbingan konseling penanganan data siswa yang meliputi data pribadi siswa, data bimbingan dan pelanggaran tata tertib siswa masih dilakukan secara manual. Banyaknya jumlah siswa dan data yang harus dimasukkan menjadi kendala dalam perekapan, pencarian dan pembaharuan data.

Berdasarkan kendala di atas, maka SMK Azza Wa Jalla Bandar Lampung membutuhkan sistem informasi bimbingan konseling yang dapat membantu dan memudahkan guru bimbingan konseling dalam melakukan pendataan, pengarsipan dan pengolahan data siswa. Selain itu sistem informasi bimbingan konseling juga diharapkan dapat membantu orang tua atau wali siswa untuk berkonsultasi dengen guru bimbingan konseling.

\section{METODE PENELITIAN}

\subsection{Metode Pengembangan Sistem}

Extreme Programming adalah metode pengembangan software yang cepat, efisien, beresiko rendah, fleksibel, terprediksi, scientific, dan menyenangkan. XP bukan hanya berfokus pada coding tetapi meliputi seluruh area pengembangan perangkat lunak (Lita dkk, 2019). Alasan menggunakan metode Extreme Programming (XP) karena sifat dari aplikasi yang dikembangkan dengan cepat melalui tahapan-tahapan yang ada meliputi : Planning, Design, Coding dan Testing.

Tahapan-tahapan Pengembangan Sistem dengan Model Extreme Programming (XP) :

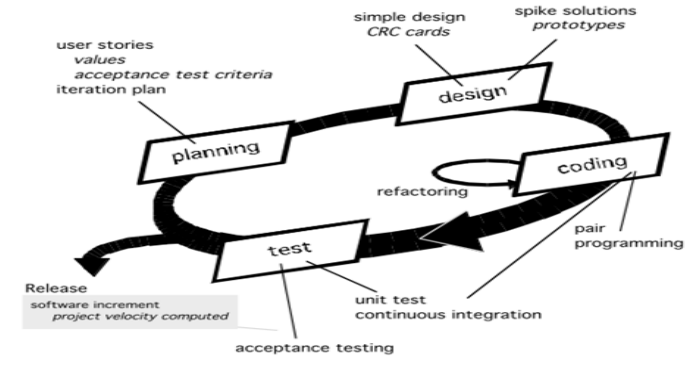

Gambar 1. Metode Pengembangan Sistem Extreme Programming. (Micheal 2015)

Tahapan-tahapan yang harus dilakukan adalah sebagai berikut :

\section{Planning}

Planning atau perencanaan adalah pemilihan atau penetapan tujuan organisasi dan penentuan strategi, kebijaksanaan, proyek, program, prosedur, metode, sistem, anggaran dan standard yang dibutuhkan untuk mencapai tujuan.Peneliti melakukan identifikasi kebutuhan dengan analisis sistem.

\section{Design}

Tahap design memutuskan bagaimana sistem akan beroperasi, dalam hal perangkat keras, perangkat lunak, dan jaringan infrastruktur antar 
muka pengguna, laporan dan program khusus, database dan file yang akan dibutuhkan. Peneliti membuat rancangan usecase, class diagram, activity diagram, input, proses, output, dan pengkodean.

\section{Coding}

Coding adalah proses menulis, menguji dan memperbaiki (debug), dan memelihara kode yang membangun sebuah program komputer. Kode ini ditulis dalam berbagai bahasa pemograman.Tujuan dari pemograman adalah untuk membuat suatu program yang dapat melakukan suatu perhitungan atau 'pekerjaan' sesuai dengan keinginan si pemogram.

\section{Testing}

Testing adalah proses yang dibuat sedemikian rupa untuk mengidentifikasi hasil sebuah sistem informasi dengan hasil yang diharap. Program yang sudah selesai akan dilakukan pengujian.

\subsection{Perencanaan Sistem}

\section{A. Kebutuhan perangkat keras}

Perangkas keras yang digunakan untuk pengelolahan data dan penyajian laporan. Perangkat keras yang digunakan dapat diuraikan sebagai berikut :

1. Laptop .

2. ProcessorAMD A8.

3. Memory minimal $4 \mathrm{~GB}$

4. Hardisk minimal $500 \mathrm{~GB}$

\section{B. Kebutuhan Perangkat Lunak (software)}

Perangkat lunak yang digunakan untuk membuat aplikasi ini menggunakan Windows10 sebagai sistem operasi dan software pendukung yaitu Xampp Control Panel, SQLyog, Notepad ++ .

\section{a. Data}

Data-data yang diperlukan dalam penelitian ini adalah data siswa dan data bimbingan konseling pada SMK Azza Wa Jalla Bandar Lampung.

\section{b. Kebutuhan Input}

Adapun kebutuhan input pada penelitian ini dapat diuraikan sebagai berikut :
1. Data siswa.

2. Data guru.

3. Data kelas.

4. Data jenis bimbingan konseling.

5. Transaksi siswa yang melakukan bimbingan konseling.

\section{c. Kebutuhan Output}

Adapun kebutuhan output pada penelitian ini dapat diuraikan sebagai berikut :

1. Laporan data siswa.

2. Laporan bimbingan konseling persiswa.

3. Laporan bimbingan konseling perbulan.

4. Laporan bimbingan konseling pertahun.

5. Hasil konsultasi untuk siswa.

\subsection{Perancangan Sistem}

\section{A. Use Case Diagram}

Diagram Use Case merupakan bagian tertinggi dari fungsionalitas yang dimiliki sistem yang akan menggambarkan bagaimana seseorang atau actor akan menggunakan dan memanfaatkan sistem. Diagram ini juga mendeskripsikan apa yang akan dilakukan oleh sistem.

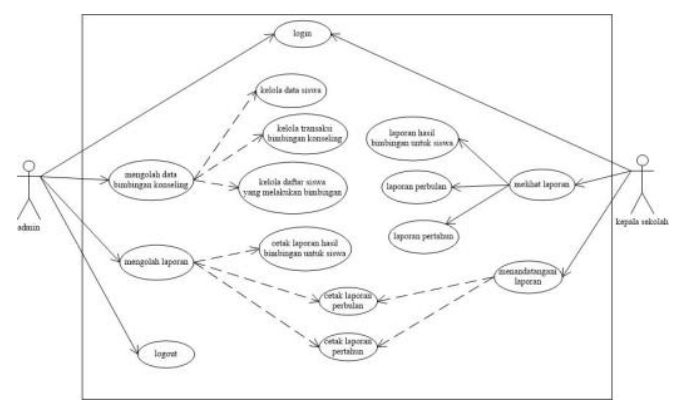

Gambar 2. Rancangan Use Case Diagram.

\section{B. Rancangan Class Diagram}

Merupakan hubungan antar kelas dan penjelasan detail tiap-tiap kelas di dalam model desain dari suatu sistem, juga memperlihatkan aturan-aturan dan tanggung jawab entitas yang menentukan perilaku sistem. Class Diagram juga menunjukkan atribut-atribut dan operasioperasi dari sebuah kelas dan constraint yang berhubungan dengan objek yang dikoneksikan (Susanto F, 2018). 


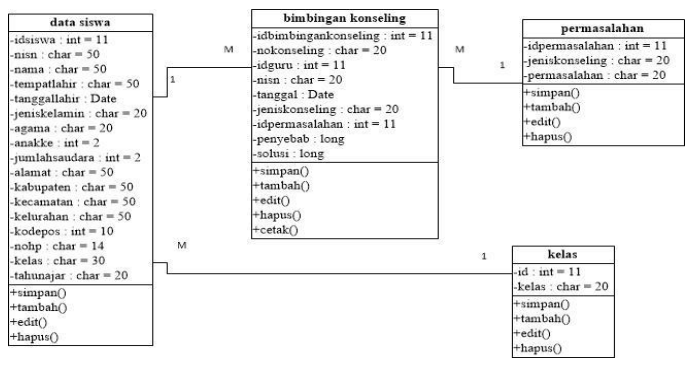

Gambar 3. Rancangan Class Diagram.

\section{Hasil dan Pembahasan}

\section{Tampilan Menu Login}

Entri password digunakan dengan cara menginputusername serta password kemudian tekan tombol login.

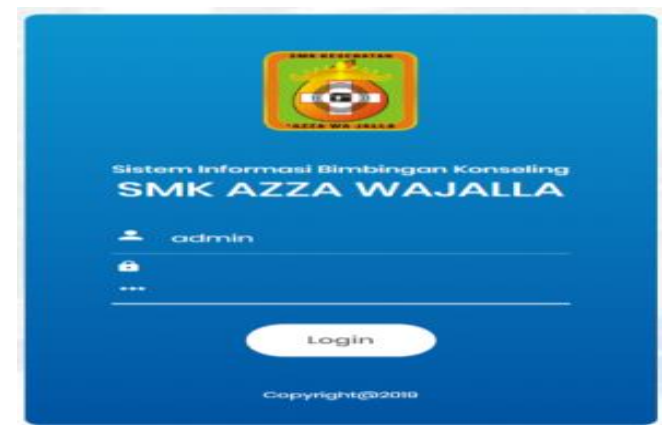

Gambar 4. Tampilan Menu Login.

\section{Tampilan Menu Utama}

Pada form menu utama ini terdapat empat menu utama diantaranya adalah master, transaksi, laporan dan logout.

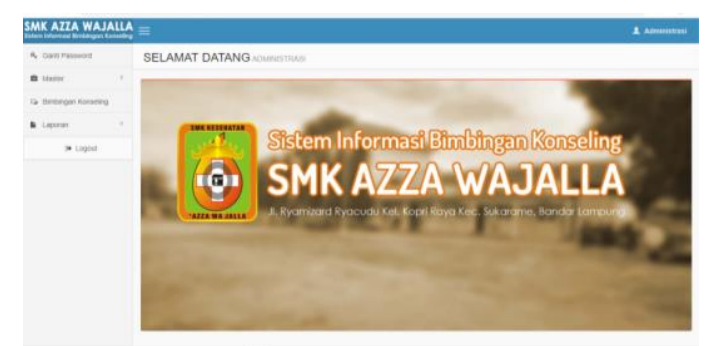

Gambar 5. Tampilan Menu Utama.

\section{Tampilan Data Siswa}

Berikut ini adalah tampilan data siswa, penguna bisa melihat data siswa, mencari data siswa dan melakukan tambah data siswa dengan mengklik tambah data siswa. Di form ini pengguna bisa melakukan edit data dan hapus data.

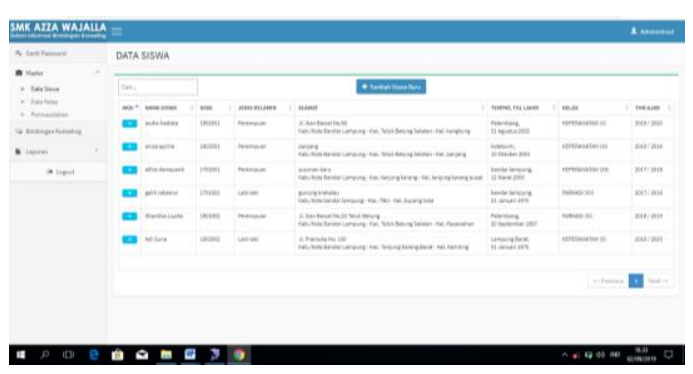

Gambar 6. Tampilan Data Siswa.

\section{Tampilan Input Data Siswa}

Berikut ini adalah tampilan inputdata siswa, penguna bisa mengentry data dengan menginput data diri siswa.

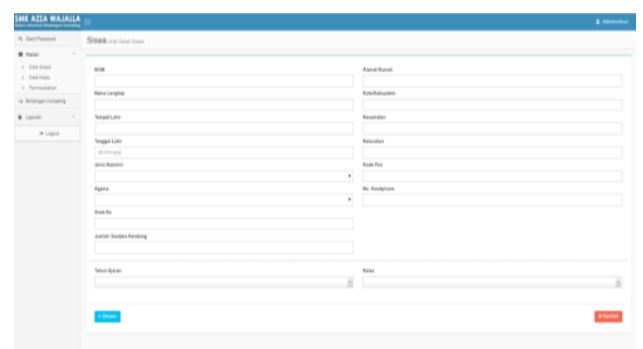

Gambar 7. Tampilan Input Data Siswa.

\section{Tampilan Data Guru}

Berikut ini adalah tampilan data guru, penguna bisa menginput gurudengan mengklik tambah guru, melihat data guru, dan mencari data. Di form ini pengguna bisa melakukan edit data dan hapus data.

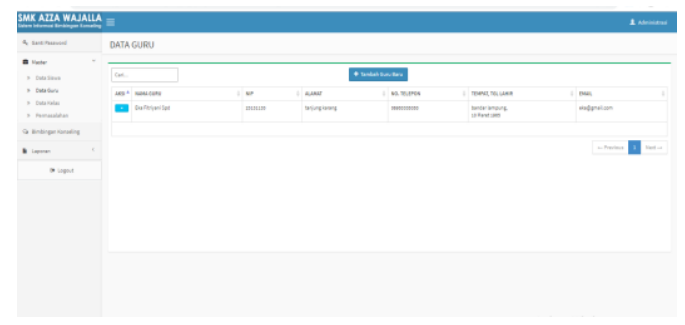

Gambar 8. Tampilan Data Guru. 


\section{Tampilan Input Data Guru}

Berikut ini adalah tampilan inputdata guru, penguna bisa mengentry data dengan menginput data guru.

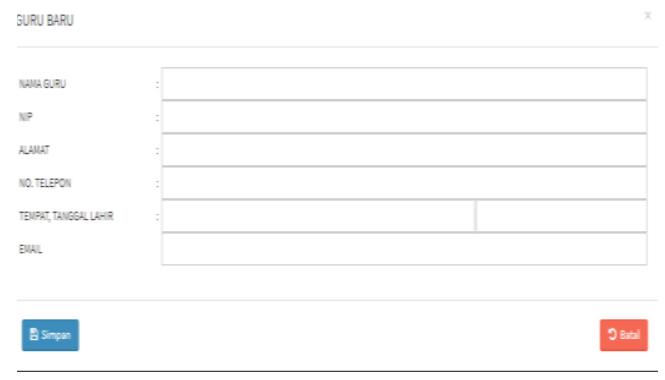

Gambar 9. Tampilan Input Data Guru.

\section{Tampilan Data Kelas}

Berikut ini adalah tampilan data kelas, penguna bisa menginput kelasdengan mengklik tambah kelas, melihat data kelas, dan mencari data. Di form ini pengguna bisa melakukan edit data dan hapus data.

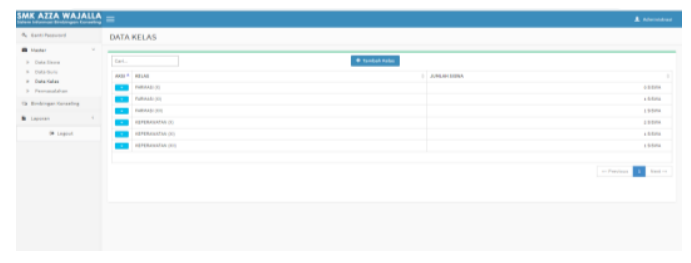

Gambar 10. Tampilan Data Kelas.

\section{Tampilan Input Data Kelas}

Berikut ini adalah tampilan inputdata kelas, penguna bisa mengentry data dengan menginput data kelas.

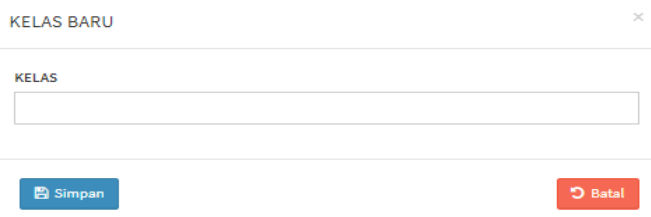

Gambar 11. Tampilan Input Data Kelas.

\section{Tampilan Bimbingan Konseling}

Berikut ini adalah tampilan bimbingan konseling, penguna bisa melihat data bimbingan konseling, mencari data bimbingan konseling dan melakukan tambah data bimbingan konseling dengan mengklik tambah bimbingan konseling. Di form ini pengguna bisa melakukan edit data, hapus data, dan cetak laporan hasil bimbingan konseling.

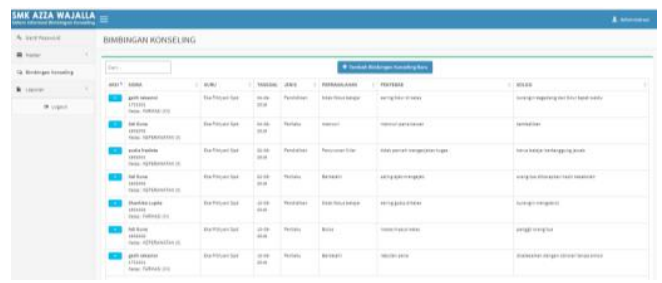

Gambar 12. Tampilan Bimbingan Konseling.

\section{Tampilan Input Bimbingan Konseling}

Berikut ini adalah tampilan inputdata bimbingan konseling, penguna bisa mengentry data dengan menginput data.

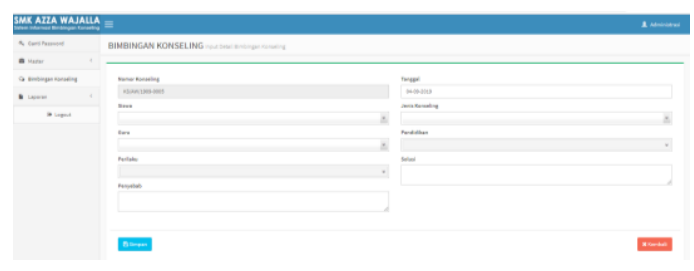

Gambar 13. Tampilan Input Bimbingan Konseling.

\section{Tampilan Input Permasalahan}

Berikut ini adalah tampilan inputdata permasalahan, penguna bisa mengentry data dengan menginput data.

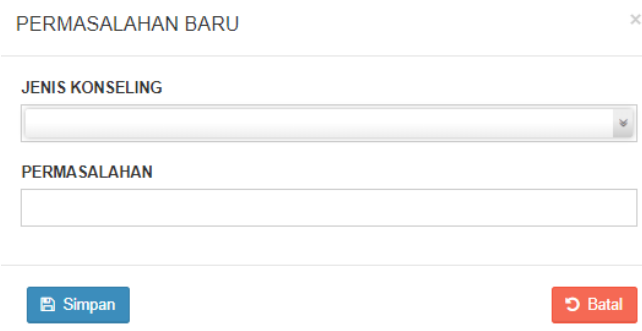

Gambar 14. Tampilan Input Permasalahan. 


\section{Tampilan Laporan Hasil Bimbingan}

\section{Konseling}

Tampilan ini dari menu bimbingan konseling yang berguna untuk mengetahui informasi tentang siswa yang melakukan bimbingan konseling dalam bentuk surat yang akan diberikan kepada orang tua/wali siswa.

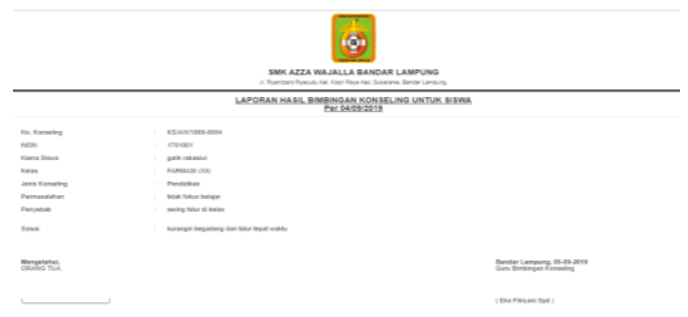

Gambar 15. Tampilan Laporan Hasil Bimbingan Konseling.

\section{Tampilan Laporan Data Siswa}

Tampilan ini dari menu laporan data siswa yang berguna untuk mengetahui informasi tentang data siswa untuk diarsipkan dan diberikan kepada kepala sekolah.

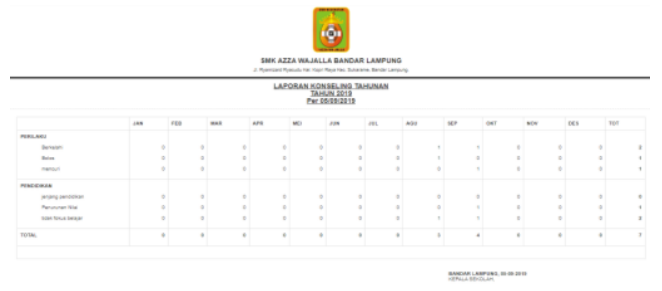

Gambar 16. Tampilan Laporan Data Siswa.

\section{Tampilan Laporan Data Konseling Persiswa}

Tampilan ini dari menu laporan data konseling persiswa yang berguna untuk mengetahui informasi tentang data siswa konseling persiswa untuk diarsipkan dan diberikan kepada kepala sekolah.

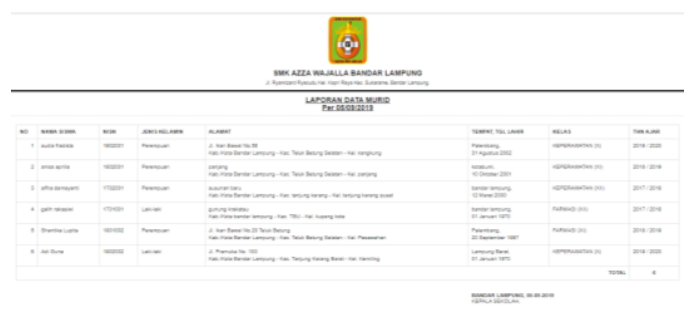

Gambar 17. Tampilan Laporan Data Konseling Persiswa.

\section{Tampilan Laporan Data Konseling Bulanan}

Tampilan ini dari menu laporan data konseling bulanan yang berguna untuk mengetahui informasi tentang data siswa konseling bulanan untuk diarsipkan dan diberikan kepada kepala sekolah.

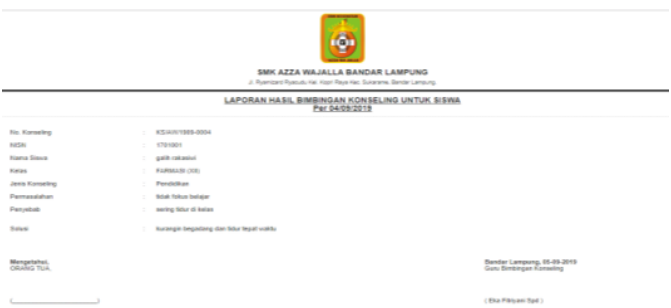

Gambar 18. Tampilan Laporan Data Konseling Bulanan.

\section{Tampilan Laporan Data Konseling Tahunan}

Tampilan ini dari menu laporan data konseling tahunan yang berguna untuk mengetahui informasi tentang data siswa konseling tahunan untuk diarsipkan dan diberikan kepada kepala sekolah.

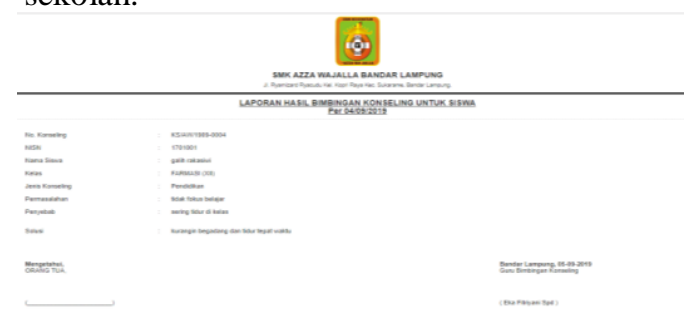

Gambar 19. Tampilan Laporan Data Konseling tahunan.

\section{KESIMPULAN}

Adapun kesimpulan dari penelitian ini adalah dengan adanya Aplikasi Sistem Informasi Bimbingan Konseling Pada Sekolah Menengah Kejuruan (SMK) AZZA WA JALLA Bandar Lampung maka laporan data siswa, laporan hasil bimbingan konseling, laporan konseling per siswa, laporan konseling bulanan, dan laporan konseling tahunan sesuai dengan standar dan kebutuhan yang efektif dan efisien.

Untuk bahan pertimbangan maka penulis memberikan saran yang sangat bermanfaat dan 
dapat membantu SMK AZZA WA JALLA Bandar Lampung untuk masa yang akan datang yaitu diharapkan aplikasi yang dihasilkan dapat dimanfaatkan dengan baik, sebelum diterapkan perlu dilakukan pelatihan (tranning).

\section{DAFTAR PUSTAKA}

[1] Dicky Eka Putra, 2018,Rancang Bangun Sistem Informasi Bimbingan

Konseling Berbasis Web Pada Smp Negeri 39, Surabaya.

[2] Ma’Mur, M., Lia, L., \& Hafiz, A. (2019). Metode Extreme Programming Dalam Membangun Aplikasi Kos-Kosan Di Kota Bandar Lampung Berbasis Web. Jurnal Cendikia,(Dalam hal ini Volume 18 No 1 halaman 377-383).

[3] Setiawan, A., Nurlaela, L., \& Yundra, E. (2019, November).
Pengembangan E Learning Sebagai Media Pembelajaran Pendidikan Vokasi. In Prosiding Seminar Nasional SANTIKA Ke-1 2019 (pp. 52-56)..

[4] Susanto, F., \& Sundari, E. (2018). Sistem Pengambilan Keputusan Penilaian Indek Kinerja Karyawan Dinas Pendapatan Kabupaten Pringsewu Dengan Pendekatan Weighted Product. Jurnal Teknologi Komputer dan Sistem Informasi, 1(2), 5-9.

[5] Yaumi, M. (2017). Integrasi Teknologi Informasi dan Komunikasi dalam Pembelajaran. Lentera Pendidikan: Jurnal Ilmu Tarbiyah dan Keguruan, 14(1), 88-102. 